\title{
High Doses of Testosterone Has Destructive Effects on Normal Cell Line in Cell Culture
}

\author{
Farahmandlou N, Heydari H*, Sagharjoghi Farahani M
}

\begin{abstract}
Testosterone mainly protects our cells from damaging effects of many chemicals. The main aim of this study was to assess the effects of testosterone on normal cell line (Hek cells) in cell culture. Hek cells were exposed to $0.001,0.01,0.1$, and $1 \mathrm{mg} / \mathrm{ml}$ of testosterone solution. MTT assay was used to determine cytotoxic effects of testosterone. Our results indicated that exposure to 0.1 and 1 $\mathrm{mg} / \mathrm{ml}$ of testosterone led to significant decrease in viability of Hek cells compared to control cells $(\mathrm{P}<0.05$ and $\mathrm{p}<0.001$, respectively). Our finding shows that high doses of testosterone have cytotoxic effects on normal cells in cell culture.
\end{abstract}

Index Terms - Testosterone, Hek, Viability.

\section{INTRODUCTION}

Testosterone is a medication and naturally occurring steroid hormone. (1) Testosterone is made primarily by the testicles in males. Small amounts are also made by the adrenal glands and the ovaries in females.(2) As a medication it is used to treat male hypogonadism and certain types of breast cancer. It may also be used to increase athletic ability in the form of doping. ${ }^{[1]}$ It is unclear if the use of testosterone for low levels due to aging is beneficial or harmful.(3) Human Embryonic Kidney 293 cells, also often referred to as HEK 293, HEK-293, 293 cells, or less precisely as HEK cells, are a specific cell line originally derived from human embryonic kidney cells grown in tissue culture. HEK 293 cells are very easy to grow and transfect very readily and have been widely used in cell biology research for many years. They are also used by the biotechnology industry to produce therapeutic proteins and viruses for gene therapy. HEK 293 cells were generated in 1973 by transformation of cultures of normal human embryonic kidney cells with sheared adenovirus 5 DNA in Alex van der Eb's laboratory in Leiden, The Netherlands. (4) According to last studies have shown that, testosterone use for treatment of males with too little or no natural testosterone production-males with hypogonadism. (5) This is known as hormone replacement therapy or testosterone replacement therapy (TRT), which maintains serum testosterone levels in the normal range. Decline of testosterone production with age has led to interest in androgen replacement therapy. (6) Other studies have shown that,

Nooshin Farahmandlou (PhD) is with Department of Molecular and Cellular Sciences, Faculty of Advanced Sciences \& Technology , Pharmaceutical Sciences Branch, Islamic Azad University, Tehran-Iran(IAUPS

Hedieh Heydari (*corresponding author) is with Department of Molecular and Cellular Sciences, Faculty of Advanced Sciences \& Technology, Pharmaceutical Sciences Branch, Islamic Azad University, Tehran-Iran(IAUPS).

Morteza Sagharjoghi Farahani is with Young Researchers and Elite Club, Islamshahr Branch, Islamic Azad University, Islamshahr, Iran.
Testosterone has been used to treat depression in men who are of middle age with low testosterone. However, a 2014 review showed no benefit on the mood of the men with normal levels of testosterone or on the mood of the older men with low testosterone. (7) Testosterone therapy may improve the management of type 2 diabetes. (8) Low testosterone has been associated with the development of Alzheimer's disease. $(9,10)$ The main aim of this study was to assess the effects of testosterone on normal cell line (Hek cells) in cell culture.

\section{MATERIAL AND METHODS}

Different concentrations $(0.001,0.01,0.1$, and $01 \mathrm{mg} / \mathrm{ml})$ of testosterone were prepared and used in our study. Hek cells (kidney normal cell line) were purchased from National Cell Bank of Iran (Pasteur Institute, Tehran, Iran). Cells were grown and incubated in standard situation. Then, cells were sub-cultured into $75 \mathrm{~cm}^{2}$ flasks, 96 -well plates or 6-well plates. Testosterone suspension was removed from media, 20 $\mu \mathrm{l}$ MTT was added to each well and incubated for 4 hours at $37 \mathrm{oC} .150$ $\mu$ isopropanol was added and covered with tinfoil and agitate cells on orbital shaker for $15 \mathrm{~min}$. Absorbance was read at $570 \mathrm{~nm}$ with a reference filter of 630 and recorded.Analyses were conducted using the SPSS 20 and ANOVA.

\section{RESULTS}

Figure 1: show that the Viability of Hek cells compared to control group. *and ** indicates significant difference compared to control group $(\mathrm{P}<0.05$ and $\mathrm{P}<0.001$, respectively).

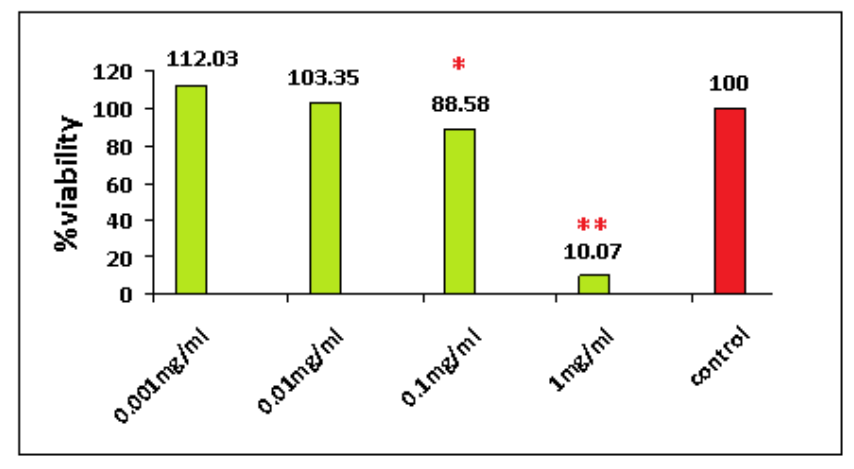

Figure I. Viability of Hek cells compared to control group. *and ** indicates significant difference compared to control group $(\mathrm{P}<0.05$ and $\mathrm{P}<0.001$, respectively).

Our results indicated that exposure to 0.1 and $1 \mathrm{mg} / \mathrm{ml}$ of testosterone led to significant decrease in viability of Hek cells compared to control cells $(\mathrm{P}<0.05$ and $\mathrm{P}<0.001$, respectively). 


\section{DISCUSSION}

According to previous studies, testosterone has effect $\mathrm{s}$ on the ultrastructure of the mouse prostate. (11) In other studies it has been shown that, elevated testosterone alters $\mathrm{InsP}_{3} \mathrm{R}$ type 1-mediated intracellular $\mathrm{Ca}^{2+}$ signaling and that the prolonged $\mathrm{Ca}^{2+}$ signals lead to apoptotic cell death. These effects of testosterone on neurons will have long term effects on brain function.(12) Last studies have shown that, short term (3 months) TE supplementation to healthy older men who have serum testosterone levels near or below the lower limit of normal for young adult men results in an increase in lean body mass and possibly a decline in bone resorption, as assessed by urinary hydroxyproline excretion, with some effect on serum lipoproteins, hematological parameters, and PSA (13) Despite protective effects of testosterone on many tissues in our body, it seems that high testosterone level may cause destructive effects on normal body cells.

\section{CONCLUSION}

According to our finding, high doses of testosterone have cytotoxic effects on normal cells in cell culture.

\section{ACKNOWLEDGMENT}

We appreciate all who helped us to exert this study.

\section{REFERENCES}

[1] Testosterone Drugs.com. American Society of Health-System Pharmacists. December 4, 2015. Retrieved 3 September 2016.

[2] Puri D (2014). Textbook of Medical Biochemistry (3 rd ed.). Elsevier Health Sciences. p. 631

[3] Staff (3 March 2015). Testosterone Products: Drug Safety Communication - FDA Cautions About Using Testosterone Products for Low Testosterone Due to Aging; Requires Labeling Change to Inform of Possible Increased Risk of Heart Attack And Stroke. FDA. Retrieved 5 March 2015.

[4] Jaluria P, Chu C, Betenbaugh M, Shiloach J. Cells by design: a mini-review of targeting cell engineering using DNA microarrays. Mol Biotechnol. 2008 Jun;39(2):105-11. https://doi.org/10.1007/s12033-008-9048-5

[5] Winn, Katherine L. Margo|Robert. "Testosterone Treatments: Why, When, and How? - American Family Physician". Retrieved2016-10-03.

[6] Myers JB, Meacham RB . "Androgen replacement therapy in the aging male". Reviews in Urology. 5 (4): 216-26.

[7] Amanatkar HR, Chibnall JT, Seo BW, Manepalli JN, Grossberg GT. "Impact of exogenous testosterone on mood: a systematic review and meta-analysis of randomized placebo-controlled trials". Annals of Clinical Psychiatry. 26 (1): 19-32.

[8] raish AM, Saad F, Guay A. "The dark side of testosterone deficiency: II. Type 2 diabetes and insulin resistance". Journal of Andrology. 30 (1): $23-32$. https://doi.org/10.2164/jandrol.108.005751

[9] Pike CJ, Rosario ER, Nguyen TV (Apr 2006). "Androgens, aging, and Alzheimer's disease".Endocrine. 29 (2): 233-41. https://doi.org/10.1385/ENDO:29:2:233

[10] Rosario ER, Chang L, Stanczyk FZ, Pike CJ (Sep 2004). "Age-related testosterone depletion and the development of Alzheimer disease". JAMA. 292 (12): 1431-32. https://doi.org/10.1001/jama.292.12.1431-b

[11] L.M. Franks, A.A. Barton. The effects of testosterone on the ultrastructure of the mouse prostate in vivo and in organ cultures. Experimental Cell Research February 1960;19(1):35-50. https://doi.org/10.1016/0014-4827(60)90035-5

[12] Estrada M, Varshney A, Ehrlich BE. Elevated testosterone induces apoptosis in neuronal cells. Journal of Biological Chemistry. 2006 Sep 1;281(35):25492-501.

https://doi.org/10.1074/jbc.M603193200
[13] Tenover JS. Effects of testosterone supplementation in the aging male. The Journal of Clinical Endocrinology \& Metabolism. 1992 Oct;75(4):1092-8.. https://doi.org/10.1210/jcem.75.4.1400877 